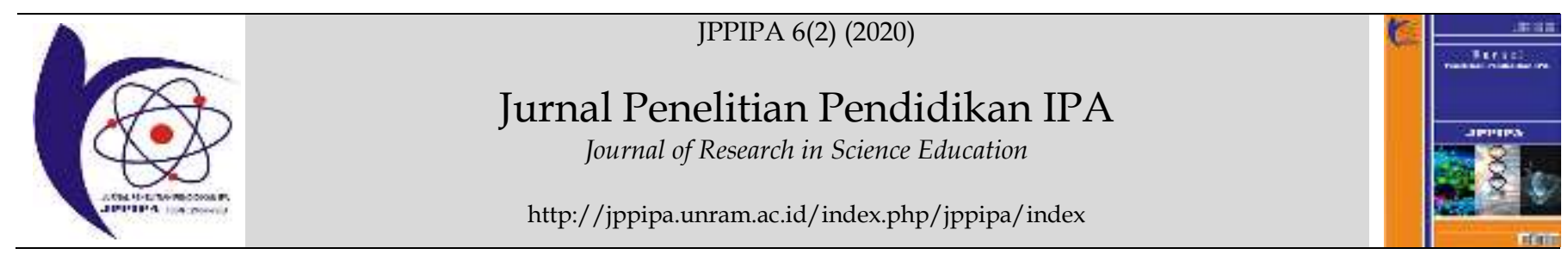

\title{
Antioxidant Activity of Fruit Extract Powder Beans (Phaseolus vulgaris L.) Using DPPH Method
}

\author{
Rizki Nugrahani ${ }^{*}{ }$, Yayuk Andayani², Aliefman Hakim² \\ ${ }^{1}$ Pharmacy Study Program, Faculty of Health Sciences, Nahdlatul Wathan University, Mataram, Indonesia. \\ ${ }^{2}$ Sciences Education Study Program, Postgraduate, Mataram University, Mataram, Indonesia
}

DOI: $10.29303 /$ jppipa.v6i2.409

\section{Article Info}

Received : March 12th, 2020

Revised : June 25th, 2020

Accepted: July $1^{\text {th }}, 2020$

\begin{abstract}
Free radical effect is one of many factors that can cause coronic desease, heart coronary desease, diabetes militus. Beans plant (Phaseolus vulgaris L.) countant antioxidant compound. Antioxidants could inhibit oxidation reaction, that is cousing free radical compounds. The objective of this research was to determine the potential of bean extracts as an antioxidant. DPPH method was used to measure antioxidant activity, absorbances was measured using UV-Vis spectroscopy. Scrining phytochemical used to identified secondary metabolites in samples. The result showed $\mathrm{IC}_{50}$ 1268.18; 2512; 1698.18 and $4442.75 \mu \mathrm{g} / \mathrm{mL}$ for all variety of stroge (less $1,1,2,3$ months) and $\mathrm{IC}_{50}$ control BHT was $1.744 \mu \mathrm{g} / \mathrm{mL}$. Extract of bean powder sample classified as very weak antioxidant activity, variety of storage could effect to antioxidant activity. Phytochemical screening results obtained flavonoids, phenols, alkaloids, saponins, steroids and terpenoids present in the sample, while tannin are not included in the sample.
\end{abstract}

Keywords: antioxidant activity; Phaseolus vulgaris L.; DPPH; $\mathrm{IC}_{50}$

Citation: Nugrahani, R., Andayani, Y., \& Hakim, A. (2020). Antioxidant Activity of Fruit Extract Powder Beans (Phaseolus vulgaris L.) Using DPPH Method. Jurnal Penelitian Pendidikan IPA (JPPIPA), 6(2), $194-198 . \quad$ doi: https://doi.org/10.29303/jppipa.v6i2.409

\section{Introduction}

One of the causes of some coronary diseases such as cancer is due to the effects caused by free radical compounds. Free radicals are molecules with free unpaired electrons and are very reactive (Lobo, et al., 2010). One method of preventing free radical formation is by using substances that can act as free radicals known as antioxidants.

Antioxidant compounds have the ability to inhibit oxidation reactions from normal metabolic processes in living things that cause free radical compounds. Antioxidants are able to give one electron to free radicals so they will produce a stable new radial (Sánchez, et al., 2016) (Hamid, et al., 2010)..
Green beans (Phaseolus vulgaris L) is one type of plant that can be a source of natural antioxidants (Kurnia, 2013). The parts of the beans are known to have great benefits because of their abundant nutritional content. Phaseolus vulgaris L contains variations in anthocyanin and antioxidant activity (Dzomba, 2013).

According to Lima et al (2014) Phaseolus vulgaris L contains large amounts of bioactive phenolic compounds. Pure flavonoid compounds such as anthocyanin, quercetin glycosides and condensed tannins found in the seeds show better and significant antioxidant activity when compared with existing synthetic antioxidants (Sihombing et al., 2010). 
Research on antioxidant activity in bean extract has been done before (Kurnia, 2013). The research used fresh extracts that were soaking using water solvents, but studies of the antioxidant activity of bean extract in powder form have never been reported. For more extensive information about the benefits of green beans as a medicinal ingredient, it is necessary to study and investigate how the antioxidant activity of bean extract in powder preparations is obtained through a heating process at high temperatures and has been stored for a certain period of time.

\section{Method}

The materials needed in this study were $\mathrm{P}$ Vulgaris L extract powder obtained from the traditional medicine industry in the town of Mataram, distilled water, DPPH merck, BHT, $96 \%$ v/v methanol, $50 \%$ v/v methanol, magnesium powder, concentrated hydrochloric acid $37 \% \mathrm{v} / \mathrm{v}$, concentrated $\mathrm{H}_{2} \mathrm{SO}_{4} 97 \%$ v/v, $\mathrm{FeCl}_{3} 1 \%$ w/v, $\mathrm{FeCl}_{3} 5 \%$ w/v, ammonia, chloroform, dragendorff reagent, meyer reagent, acetate anhydride, amyl-alcohol.

The tools that will be needed in this research are analytical balance, volumetric pipette, porcelain cup, water bath, water bath, incubator, desiccator, Shimadzu UV-1800 spectrophotometer, glassware, GF silica gel palate, fortex, TLC chamber, sprayer, filter paper cotton and aluminum foil.

The material used in this study is the extract of beans obtained from the immersion process of fresh fruit using water which is then processed to form a powder with a heating method. The process of making extract powder is carried out by a traditional drug production house in the city of Mataram. There are four types of samples based on sample age namely 0 months, 1 month 2 months and 3 months calculated from the extract made. Each sample used has a different production date, not one batch.

The material used in this study is the extract of beans obtained from the immersion process of fresh fruit using water which is then processed to form a powder with a heating method. The process of making extract powder is carried out by a traditional drug production house in the city of Mataram. There are four types of samples based on sample age namely 0 months, 1 month 2 months and 3 months calculated from the extract made. Each sample used has a different production date, not one batch.

A number of samples were dissolved with $\mathrm{CHCl}_{3}$ (chloroform) and $\mathrm{NH}_{4} \mathrm{OH}$ then filtered and the filtrate was put into a closed test tube $\mathrm{CHCl}_{3}$ extract was then added $2 \mathrm{M} \mathrm{H}_{2} \mathrm{SO}_{4}$, until 2 layers were formed. The acid layer above the meyer reaction is added which produces a white precipitate while the addition of dragendorff reagents which will cause an orange-red precipitate.

A number of sample powders were dissolved with water then heated to boiling. After that, it is filtered and the filtrate is used as a test solution. The filtrate is put into a closed test tube then shaken for 10 seconds. The presence of saponins is indicated by the formation of stable froth.

A number of sample powders were dissolved with methanol. The solution is filtered, the filter results are then evaporated on the Waterbath. The evaporated extract was dissolved with chloroform, then added with anhydrous acetate, then the mixture was dropped with concentrated $\mathrm{H}_{2} \mathrm{SO}_{4}$ through the test tube wall. The presence of triterpenes is indicated by brownish or violet rings at the boundaries of two solvents, while the appearance of green indicates steroids.

A number of samples (0.1 gr) were extracted with $20 \mathrm{ml}$ of $70 \%$ methanol. The resulting solution was taken as much as $1 \mathrm{ml}$ and then added $5 \% \mathrm{FeCl}_{3}$. A positive reaction is shown by the formation of green or bluish green.

A number of extract powder dissolved with water then boiled for 5 minutes and filtered. Part of the filtrate obtained was added with a $1 \% \mathrm{FeCl}_{3}$ solution. Positive results are shown by the formation of a blackish green color.

Analysis of Antioxidant compounds Using Thin Layer Chromatography Techniques (TLC). As much as 0.5 grams of bean extract powder that has been dissolved with $25 \mathrm{ml}$ methanol solvent, TLC was carried out using a mixture of methanol and chloroform with a ratio of 1:39. After elution is complete, the plates are dried and sprayed with a $0.5 \mathrm{mM}$ DPPH solution in methanol. Positive anti-free radical tests produce yellow spots on a purple background in about 30 minutes. A qualitative antioxidant activity test was also carried out on BHT used as a standard antioxidant.

Antioxidant Activity Test with DPPH Color Immersion by the process of making a $0.5 \mathrm{Mm} \mathrm{DPPH}$ solution, weigh rapidly \pm 19.7 grams $\mathrm{DPPH}$, then dissolve it with methanol p.a until the volume is exactly $100 \mathrm{~mL}$ in a volumetric flask and beaten. The solution is stored in a dark colored bottle.

Determination of the maximum wavelength DPPH solution is by dissolving $0.5 \mathrm{mM} \mathrm{DPPH}$ in methanol measured wavelengths ranging from wavelengths of $450 \mathrm{~nm}-600 \mathrm{~nm}$. Determination of Antioxidant Activity through the following process: $\mathrm{P}$ Vulgaris L. extract powder was dissolved in methanol and made in various concentrations of 200, 400, 800, 1600, 3200 and $6400 \mathrm{ppm}$ respectively $10 \mathrm{ml}$. Each solution is added with $1 \mathrm{ml}$ of $0.5 \mathrm{mM}$ DPPH solution and soaked for 30 minutes in a dark room so that the 
reaction is more perfect (Wardatun, 2011), then measured at the maximum wavelength predetermined. As a blank solution methanol was added with a $0.5 \mathrm{mM}$ DPPH solution. As for positive control BHT used with concentrations of $1,2,3,4,5$ and $6 \mathrm{ppm}$ added $1 \mathrm{ml}$ of $0.5 \mathrm{mM}$ DPPH solution.

Absorption measurement process by means of a test solution with a concentration variation incubated in a dark room for \pm 30 minutes then the absorption was measured at a maximum wavelength of $517 \mathrm{~nm}$ using a UV-Vis spectrophotemeter.

The method of calculation is the percentage of inhibition calculated using the formula: resistance $=$ \{(blank absorption/ sample absorption) $x 100 \%$ \}/blank absorption. $\mathrm{IC}_{50}$ values are calculated by linear regression equations obtained from the inhibitory percentages and concentration relationship curves

\section{Result and Discussion}

The results of phytochemical screening of samples of powdered bean extract (Phaseolus vulgaris L) which varied their storage time were based on the color changes caused when the samples were reacted with certain reagents. The results obtained are flavonoids, phenols, alkaloids, saponins, steroids and triterpenoids (Table 1). Tannin compounds were not found in all sample variations. These results are consistent with the results of previous studies that the extract of beans contains flavonoids and several types of polyphenol compounds (Dzomba, et al., (2013), Sihombing, et al., (2010) and Kurnia (2013)). The presence of secondary metabolite content is expected to be an indication of what compounds will act as antioxidants in bean extract powder.
Table 1. Phytochemical Test Results

\begin{tabular}{lcccc}
\hline Chemical & \multicolumn{5}{c}{ Storage time (month) } \\
\cline { 2 - 5 } Compounds & $<1$ & 1 & 2 & 3 \\
\hline Flavonoid & + & + & + & + \\
Alkaloid & + & + & + & + \\
Saponin & + & + & + & + \\
Tanin & - & - & - & - \\
Fenol & + & + & + & + \\
Steroid/triterpenoid & $+/+$ & $+/+$ & $+/+$ & $+/+$ \\
\hline
\end{tabular}

The results of the analysis of antioxidant compounds by TLC technique can be seen that after spraying with a $0.5 \mathrm{mM}$ DPPH solution. The eluen used as the mobile phase is methanol and chloroform with a ratio of 1:39, the results obtained are yellow spots with a purple background patches have Rf values of 0.36 , 0.48 and 0.61 (Figure 1).

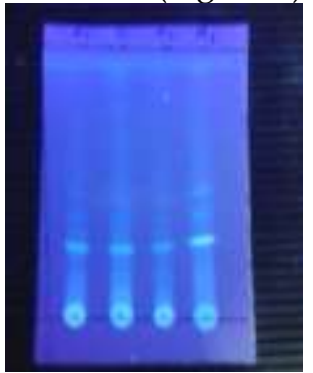

(a)

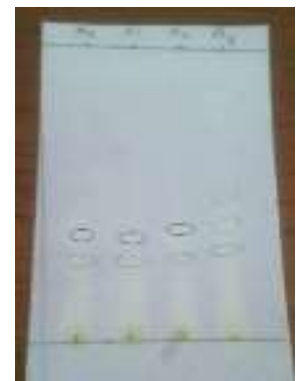

(b)
Figure 1. Test results for Activity Content with TLC (a) Under UV Lamp 366 nm (b) After DPPH Spraying.

Testing antioxidant activity with DPPH is used to see the $\mathrm{IC}_{50}$ value, which is the concentration needed to inhibit $50 \%$ of free radicals. The percentage inhibition and $\mathrm{IC}_{50}$ values for each sample are presented in Table 2

Table 2. Antioxidant Activity Test Results

\begin{tabular}{|c|c|c|c|c|c|c|c|}
\hline \multirow{2}{*}{ Storage time } & \multicolumn{6}{|c|}{$\%$ inhibition and concentration (ppm) } & \multirow{2}{*}{$\begin{array}{l}\mathrm{IC}_{50} \\
(\mu \mathrm{g} / \mathrm{mL})\end{array}$} \\
\hline & 200 & 400 & 800 & 1600 & 3200 & 6400 & \\
\hline$<1$ month & 17,97 & 21,09 & 52,54 & 81,45 & 92,58 & 90,63 & 1268,18 \\
\hline 1 month & $-5,27$ & 2,34 & 28,52 & 59,38 & 91,80 & 91,60 & 2512 \\
\hline 2 months & $-2,93$ & 26,37 & 49,41 & 85,16 & 91,80 & 88,67 & 1698,18 \\
\hline 3 months & $-3,52$ & 0,59 & 6,45 & 18,55 & 39,26 & 72,66 & 4442,75 \\
\hline $\mathrm{BHT}$ & 37,70 & 51,56 & 68,95 & 74,80 & 83,01 & 8418 & 1,744 \\
\hline
\end{tabular}

From the data in Table 2 below it is known that the greater the concentration of the sample used the greater the percentage of inhibition increases. The percentage of maximum inhibition for samples with a storage life of less than 1 month - 2 months is at a concentration of $3200 \mathrm{ppm}$ and has decreased thereafter. For samples with 3 months storage requires greater concentration to achieve the maximum percentage of inhibition. The storage period of the sample has an influence on the value of percent inhibition seen that fresh samples stored for less than 1 month when compared to samples stored for 3 months, the percentage of inhibition has decreased very significantly for each variation of concentration, this is relevant to the results obtained by Eveline, et al., (2014) and research Febrianti, et al., (2014) on purple sweet potatoes. The effect of storage on antioxidant activity in this study was not shown by data on a significant decrease in antioxidant activity for each storage time 
given to this sample because the sample used had a different date or production date.

The antioxidant activity test of bean extract powder was carried out by immersion reaction using the DPPH radical (2,2-diphenyl-1-picrylhydrazyl). The reaction between DPPH and antioxidants is illustrated in Figure 2.<smiles>O=[N+]([O-])c1cc([N+](=O)[O-])c(NN(c2ccccc2)c2ccccc2)c([N+](=O)[O-])c1</smiles><smiles>[R]O[N+](=O)c1cc([N+](=O)[O-])cc([N+](=O)[O-])c1NN(c1ccccc1)c1ccccc1</smiles>

DPPH
The working principle of free radical inhibition by antioxidants is to convert DPPH radicals which are reactive and unstable compounds into stable compounds by means of antioxidant compounds that will donate one $\mathrm{H}$ atom or one electron to an unpaired DPPH compound. Reduction reaction occurs between

DPPH and antioxidants are marked by a color change that occurs, the color of the purple DPPH solution will turn yellow after the addition of antioxidant compounds. The antioxidant activity test using the DPPH method is very easy to do because the reaction can be directly observed both using the TLC method and with simple spectrophotometry (Kedara and Singh, 2011).

The amount of immersion activity is expressed as IC50 value, which is the concentration of the substrate (in this case the concentration of antioxidant compounds) which can cause a $50 \%$ loss of DPPH radical activity (Molyneux, 2004). IC50 value calculations using the regression equation obtained from the relationship curve percentage inhibition power and variation in sample concentration (Figure 3 ).

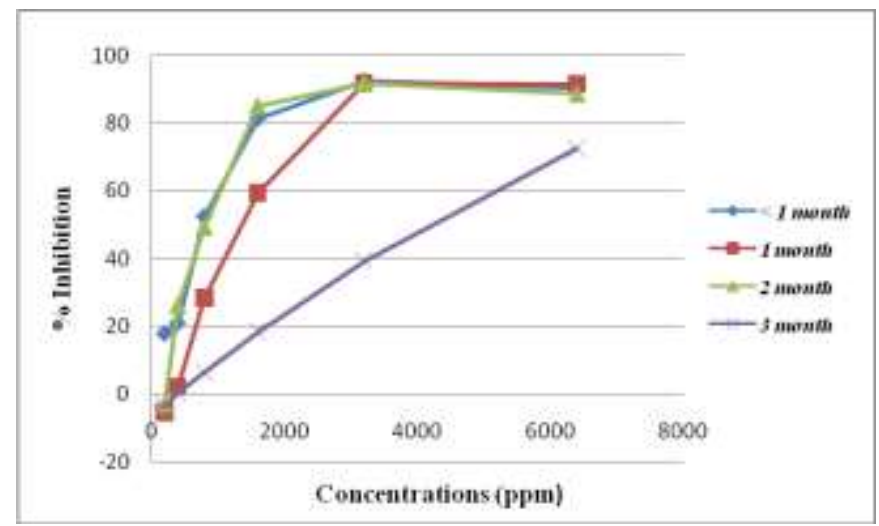

Figure 3. Graph of \% Inhibition and concentration
Table 2 shows that all samples have an $\mathrm{IC}_{50}$ value $>500 \mu \mathrm{g} / \mathrm{mL}$, this value is much greater than the $\mathrm{IC}_{50}$ BHT value used as a positive control of 1,744 $\mu \mathrm{g} / \mathrm{mL}$. From these data it can be categorized that the antioxidant compounds contained in the bean powder samples are classified as very weak antioxidants (Ciptaningsih, 2012). This is probably caused by heating at high temperatures given during the process of making ketal extract into powder preparations. Besides the extract used is not derived from extracts that have been purified so that there are many types of compounds that are still contained therein. The classification of antioxidant power is based on $\mathrm{IC}_{50}$ values, the smaller the $\mathrm{IC}_{50}$ value the stronger antioxidant activity (Molyneux, 2004).

\section{Conclusion}

Beans extract powder samples showed antioxidant activity with $\mathrm{IC}_{50}$ values for samples with storage less than 1, 1, 2, 3 months respectively 1268.18 , 2512, $1698.18 \mu \mathrm{g} / \mathrm{ml}$ and $4442.75 \mu \mathrm{g} / \mathrm{ml}$. Phytochemical screening shows samples containing chemical compounds flavonoids, alkaloids, saponins, phenols, steroids and triterpenoids. The data obtained showed that the strength of the antioxidant activity of bean extract powder samples was classified as very weak compared to BHT which had a smaller $\mathrm{IC}_{50}$ value.

\section{Acknowledgements}

Thank you to Dr. Yayuk Andayani, M.Si for the direction and financial assistance given as well as Dr. Aliefman Hakim for guidance during the course of the study.

\section{References}

Ciptaningsih, E. (2012). Uji Aktivitas Antioksidan dan Karakteristik Fitokimia pada Kopi Luwak Arabika dan Pengaruhnya terhadap Tekanan Darah Tikus Normal dan Tikus Hipertensi. Tesis. Universitas Indonesia

Dzomba, P. (2013). Anthocyanin content and antioxidant activities of common bean species (Phaseolus vulgaris L.) grown in Mashonaland Central, Zimbabwe. African Journal of Agricultural Research, 8(25), 3330-3333. https://doi.org/10.5897/AJAR12.225

Eveline., Siregar., \& Sanny. (2014). Studi Aktifitas Antioksidan pada Tomat (Lycopersicon Esculentum) Konvensional dan Organik Selama Penyimpanan. Jurusan Teknologi Pangan, Fakultas Sain dan Teknologi, Universitas Pelita Harapan, Lippo Karawaci, Tangerang. 
Febrianti, A., Dwiyanti, G., Siswaningsih, W. (2014). Pengaruh Suhu Dan Lama Pemanasan Terhadap Aktivitas Antioksidan dan Total Antioksidan Minuman Sari Ubi Jalar Ungu (Ipomea batatas L). Jurnal Sain dan Teknologi Kimia. 5 (2), 85-95

Hamid, A. A., Aiyelaagbe, O. O., Usman, L. A., Ameen, O. M., \& Lawal, A. (2010). Antioxidant: Its Medicinal and Pharmacological Application. African Journal of Pure and Applied Chemistry, 4(August), 1-4.

Kedare, S.B., Singh, R.P. (2011). Genesis and development of DPPH method of antioxidant assay. J Food Sci Technol, 48, 412-422. https:// doi.org/10.1007/s13197-011-0251-1

Kurnia, N. (2013). Uji Aktivitas Antioksidan Ekstrak Air Buah Buncis (Pheseolus vulgaria L.). Tesis. Mataram University.

Lima, P.F.D., Colombo, C.A., Chiorato, A.F., Yamaguchi, L. F., Kato, M. J., \& Carbonell, S.A.M. (2014). Occurrence of Isoflavonoids in Brazilian Common Bean Germplasm (Phaseolus vulgaris L.). Jurnal Agricultural and Food Chemistry. 62:9699-9704. https://doi.org/10.1021/jf5033312

Lobo, V., Patil, A., Phatak, A., \& Chandra, N. (2010). Free radicals, antioxidants and functional foods: Impact on human health. Pharmacognosy Reviews, 4(8), 118-126. https://doi.org/10.4103/09737847.70902

Molyneux, P. (2003). The Use of the Stable Free Radical Diphenylpicryl-hydraziyl (DPPH) for Estimating Antioxidant Activity. U. K.

Sánchez, N. F. S., Coronado, R. S., Cañongo, C. V., \& Carlos, B. H. (2016). Antioxidant Compounds and Their Antioxidant Mechanism. Intech, i(tourism), 13.

https://doi.org/http://dx.doi.org/10.5772/5735 $\underline{3}$

Sihombing, N.C. (2010). Formula Gel Antioksidan Ekstrak Buah Buncis (Phaseulus vulgaris L) dengan Menggunakan Basis AQUPEC 505 HV. Jurnal ilmiah universitas padjadjaran.

Wardatun, S. (2011). Uji Aktivitas Antioksidan Ekstrak Etanol Akar, Kulit Batang dan Daun Tanaman Sambiloto (Andrigraphis paniculata Ness.) Dengan Metode Linoleat-Tiosianat. Jurnal Fitofarmaka 1(2). 9-13. 